\title{
Anaerobic degradation of dairy wastewater in intermittent UASB reactors: influence of effluent recirculation
}

\author{
C.S. Couras, V.L. Louros, T. Gameiro, N. Alves, A. Silva, M.I. Capela, L.M. Arroja \\ \& H. Nadais
}

To cite this article: C.S. Couras, V.L. Louros, T. Gameiro, N. Alves, A. Silva, M.I. Capela, L.M. Arroja \& H. Nadais (2015) Anaerobic degradation of dairy wastewater in intermittent UASB reactors: influence of effluent recirculation, Environmental Technology, 36:17, 2227-2238, DOI: 10.1080/09593330.2015.1025102

To link to this article: http://dx.doi.org/10.1080/09593330.2015.1025102

Accepted author version posted online: 24

Mar 2015.

Published online: 17 Apr 2015.

Submit your article to this journal $₫$

山 Article views: 167

Q View related articles $\longleftarrow$

View Crossmark data ־

Citing articles: 1 View citing articles ¿ð 


\title{
Anaerobic degradation of dairy wastewater in intermittent UASB reactors: influence of effluent recirculation
}

\author{
C.S. Couras ${ }^{\mathrm{a}, \dagger}$, V.L. Louros ${ }^{\mathrm{a}}$, T. Gameiro ${ }^{\mathrm{a}}$, N. Alves ${ }^{\mathrm{a}}$, A. Silva ${ }^{\mathrm{a}}$, M.I. Capela ${ }^{\mathrm{b}}$, L.M. Arroja ${ }^{\mathrm{b}}$ and H. Nadais ${ }^{\mathrm{b} *}$ \\ ${ }^{a}$ Environment and Planning Department, University of Aveiro, Campus de Santiago, 3810-193 Aveiro, Portugal; ${ }^{b}$ CESAM-Centre for \\ Environmental and Marine Studies \& Environment and Planning Department, University of Aveiro, Campus de Santiago, 3810-193 \\ Aveiro, Portugal
}

(Received 18 May 2014; accepted 27 February 2015)

\begin{abstract}
This work studied the influence of effluent recirculation upon the kinetics of anaerobic degradation of dairy wastewater in the feedless phase of intermittent upflow anaerobic sludge bed (UASB) reactors. Several laboratory-scale tests were performed with different organic loads in closed circuit UASB reactors inoculated with adapted flocculent sludge. The data obtained were used for determination of specific substrate removal rates and specific methane production rates, and adjusted to kinetic models. A high initial substrate removal was observed in all tests due to adsorption of organic matter onto the anaerobic biomass which was not accompanied by biological substrate degradation as measured by methane production. Initial methane production rate was about $45 \%$ of initial soluble and colloidal substrate removal rate. This discrepancy between methane production rate and substrate removal rate was observed mainly on the first day of all experiments and was attenuated on the second day, suggesting that the feedless period of intermittent UASB reactors treating dairy wastewater should be longer than one day. Effluent recirculation expressively raised the rate of removal of soluble and colloidal substrate and methane productivity, as compared with results for similar assays in batch reactors without recirculation. The observed bed expansion was due to the biogas production and the application of effluent recirculation led to a sludge bed contraction after all the substrates were degraded. The settleability of the anaerobic sludge improved by the introduction of effluent recirculation this effect being more pronounced for the higher loads.
\end{abstract}

Keywords: UASB reactor; dairy wastewater; feedless period; effluent recirculation; kinetics

\section{Introduction}

In recent years, the application of anaerobic digestion for the treatment of organic waste has emerged spectacularly and the amount of anaerobically digested substrate from waste has increased at an annual growth rate of 25\%.[1,2] Considerable amounts of lipid-rich waste are produced by the food processing industry, slaughterhouses, the edible oil industry, the dairy products industry and olive oil mills.[2] In all these waste streams, lipids are often the main and most problematic substrate.[3] At high concentrations, lipids cause different types of problems in anaerobic digesters, including clogging, adsorption to biomass (causing mass transfer problems) and microbial inhibition due to the degradation to, and hence presence of, long-chain fatty acids (LCFA).[4]

Dairy wastewater having a high fat content has the highest methane potential among several types of agrowastes.[5] Anaerobic biodegradability tests indicated that $91 \%$ of the organic matter present in the effluent from milk pasteurization and cheese manufacturing without whey segregation was degraded in anaerobiosis.[6] Debowski et al. [7] studied the anaerobic degradation of dairy wastewaters in batch reactors with chemical oxygen demand (COD) loads ranging from 1.0 to $3.0 \mathrm{~kg} \mathrm{COD} \mathrm{m}^{-3}$. Depending on the load applied, the effectiveness of the treatment process ranged from $62.8 \%$ to $71.4 \%$. The authors also found that it was possible to achieve a high production of biogas with methane content over $60 \%$ in the anaerobic treatment of wastewaters from the dairy industries. The respirometric analyses demonstrated that the quantity of the gaseous products of methane fermentation and their composition were directly influenced by the applied load. A tendency was observed for decreasing effectiveness of the fermentation process with increasing quantities of wastewater fed to the anaerobic system.

Nadais [8] studied the kinetic parameters of anaerobic treatment of milk substrates in lab-scale batch reactors for various types of anaerobic sludge with different degrees of adaptation to the substrate. The Monod kinetic parameters (see Equation (1)) were determined as follows: maximum substrate removal rate ' $q_{\max }$ ' $\left(\mathrm{d}^{-1}\right) 0.6-2.2$ and half-velocity constant ' $K_{\mathrm{s}}$ ' $\left(\mathrm{mg} \mathrm{COD} \mathrm{L}{ }^{-1}\right) 7700-19000$.

*Corresponding author. Email: nadais@ua.pt

${ }^{\dagger}$ C.S. Couras and V.L. Louros contributed equally to the work. 
Saléh et al. [9] reported a study on the kinetic parameters of the treatment of dairy wastewater in a lab-scale upflow anaerobic sludge bed (UASB) with hydraulic retention time (HRT) between 20 and $44 \mathrm{~h}$ and observed a tendency for a rise in the outflow COD with the decrease in the HRT. The ranges of the kinetic parameters determined with the Monod Model were as follows: sludge yield ' $Y$ ' (mgCOD $\mathrm{mg}^{-1} \mathrm{VS} \mathrm{d}^{-1}$ ) 0.5914-0.8214; endogenous decay coefficient ' $K_{\mathrm{d}}$ ' $\left(\mathrm{d}^{-1}\right)$ 0.005619-0.007804; maximum growth rate ' $\mu_{\max }$ ' $\left(\mathrm{d}^{-1}\right) 0.1811-0.2516$; and half-velocity constant ' $K_{\mathrm{s}}$ ' (mg CODL ${ }^{-1}$ ) 611.70-849.60. A laboratory study [10] was devised to verify the use of Monod kinetics for the modelling of continuous UASB reactors treating ice cream wastewater. Eight different HRTs (5.0-0.4 d) were investigated at an average influent COD concentration of $5.2 \mathrm{~g} \mathrm{~L}^{-1}$. The maximum substrate removal rate and half-velocity constant were determined to be $1.4 \mathrm{~kg} \mathrm{COD}$ (removed) $\mathrm{kg}^{-1} \mathrm{VSS} \mathrm{d}^{-1}$ and $0.3 \mathrm{~kg} \mathrm{COD} \mathrm{kg}^{-1}$ $\mathrm{VSS} \mathrm{d}^{-1}$ (volatile suspended solids (VSS)), respectively. The yield coefficient and sludge decay rate coefficient were also determined to be $0.16 \mathrm{~kg} \mathrm{VSS} \mathrm{kg}^{-1} \mathrm{COD}$ (removed) and $0.028 \mathrm{~d}^{-1}$, respectively. The close relationship between biomass loading rate and specific substrate utilization rate supported the use of Monod equations and allowed the model to be used predictively for assessing plant performance.

Tauseef et al. [11] present a thorough review of literature results concerning energy recovery from wastewaters with high-rate anaerobic reactors. Presently, the UASB systems are the most used anaerobic technology for the treatment of industrial wastewaters.[12,13] Latif et al. [14] discussed UASB reactors' performance in the treatment of various types of wastewaters including dairy wastewater. For dairy wastewaters, the reported COD removal efficiencies ranged from $64 \%$, for an organic loading rate (OLR) of $0.24 \mathrm{kgCOD} \mathrm{L}^{-1} \mathrm{~d}^{-1}$ and a HRT of 1.5 days [15] to $98 \%$ for an OLR of $6.2 \mathrm{~kg} \mathrm{COD} \mathrm{m}^{-3} \mathrm{~d}^{-1}$ at a HRT of 6 days.[16] Tawfik et al. [17] studied the UASB treatment of dairy wastewater with $1 \mathrm{~d}$ HRT and volumetric flow of $0.5 \mathrm{~L} \mathrm{~d}^{-1}$ and OLR of $1.9-4.4 \mathrm{kgCOD} \mathrm{m}^{-3} \mathrm{~d}^{-1}$ achieving COD removal efficiencies of $69 \%$. In a pilotscale UASB treating dairy wastewater, Saléh et al. [9] achieved COD removal efficiencies of $93.5 \%$ at OLR of $1.6 \mathrm{kgCOD} \mathrm{m}^{-3} \mathrm{~d}^{-1}$ and HRT of $36 \mathrm{~h}$. JedrzejewskaCicinska et al. [18] reached COD removal efficiencies of $79.4 \%$ and $86.5 \%$ for continuous lab-scale UASB and hybrid UASB, respectively, for OLR of $4 \mathrm{~kg} \mathrm{COD} \mathrm{m}^{-3} \mathrm{~d}^{-1}$ and HRT of $24 \mathrm{~h}$.

Performance parameters were studied [19] in an alternative full-scale dairy effluent treatment system comprising two anaerobic sludge blanket reactors in parallel arrangement with upward flow, internal fat-separation by flotation, external lamella settler and floated material digester. Reactors were initially inoculated with flocculent sludge and granulated in a high-load stage. Using loading rates up to a maximum $5.5 \mathrm{~kg} \mathrm{COD} \mathrm{m}^{3} \mathrm{~d}^{-1}$ hydraulic residence time of $17 \mathrm{~h}$ reactor efficiency was found to remain stable around $90 \%$ of COD. Average sludge digester efficiency using a loading rate of $3.5 \mathrm{kgVS} \mathrm{m}^{3} \mathrm{~d}^{-1}$ with a lipid content of $47 \%$ of COD amounted to $78 \%$ of volatile solids (VS) $(87 \%$ of lipid removal).

A UASB reactor was operated at different HRTs, of about 12, 16, 20 and 18h.[20] The initial (start-up) biological OLR was about $0.054 \mathrm{~kg}$ BOD kg TVS ${ }^{-1} \mathrm{~d}^{-1}$ (biological oxygen demand (BOD)). The observed removal efficiencies of organic matter in terms of COD were about $24 \%, 39 \%, 43 \%$, and $52 \%$. The best results related to the removal of organic matter were obtained with the higher HRTs of 20 and $18 \mathrm{~h}$.

Improvements in UASB reactors allow the degradation of dairy wastewater without previous fat removal $[19,21]$ with important reduction in installation and operation costs $[13,19]$ and lower environmental impacts.[19]

The performance of anaerobic reactors is generally assessed in terms of COD removal efficiency which for dairy wastewaters may attain values as high as 98\%.[16] Yet, the COD removal efficiency is substantially higher than the biodegradation efficiency as measured by the methanization efficiency.[22,23] When the performance of UASB reactors is assessed in terms of methanization efficiency, it is apparent that presently, these systems face significant challenges in what concerns their applicability to the treatment of complex lipid-rich wastewater of which dairy wastewater is an example.[24]

Nadais et al. [22] verified that to keep the methanization efficiency above $70 \%$, continuous UASB reactors inoculated with flocculent biomass and used for treating dairy wastewater should not be operated at loading rates above $2.5 \mathrm{~g} \mathrm{COD} \mathrm{L}^{-1} \mathrm{~d}^{-1}$. Jeganathan et al. [25] reported that the continuous operation of an UASB reactor used for treating food processing wastewater resulted in $75 \%$ substrate biodegradation at a load of $2.5 \mathrm{~kg} \mathrm{COD} \mathrm{m}^{-3} \mathrm{~d}^{-1}$ and that the system performance degraded sharply for higher loads. For a load rate of $5 \mathrm{~kg} \mathrm{COD} \mathrm{m}{ }^{-3} \mathrm{~d}^{-1}$, the authors observed fats accumulation in the sludge bed and scum formation, resulting in biodegradation below 50\%. As an option to overcome operating problems verified in continuous systems, [25-28] studies have been developed on the intermittent operation of UASB reactors used for treating dairy wastewater [27,29] or for treating proteinaceous wastewater,[30] slaughterhouse wastewater,[31] domestic wastewater [32] or olive mill wastewater.[33] The beneficial effects of discontinuous feeding of fatty substrates on anaerobic systems have also been confirmed by Palatsi et al. [34] and some results obtained in a full-scale reactor are presented by Passeggi et al. [19] with effluent recirculation during the feedless phase. The intermittent operation is composed of a succession of feed and feedless periods where a feed period followed by a feedless period forms an intermittent cycle. During the feed periods, 
high substrate removal rates are achieved which are not accompanied by the expected methane production, leading to heavy accumulation of non-degraded substrate onto the biological biomass that constitutes the UASB. The feedless period is crucial for the degradation of the complex substrates (fats and LCFA) that accumulate in the biomass during the feed period, mainly by adsorption mechanisms.[22,27,29,33] During the feed periods, the intermittent UASB reactor operates as a continuous reactor and during the feedless periods, it works as a batch reactor. It has been suggested that effluent recirculation during the feedless periods of intermittent operation was beneficial for reactor performance, especially in terms of methane production.[21]

The operation of intermittent UASB reactors applied to the treatment of dairy wastewaters resulted in a COD removal efficiency of $90-97 \%$ at OLRs of $12.5-22 \mathrm{~kg}$ $\mathrm{COD} \mathrm{m}^{-3} \mathrm{~d}^{-1}$ and at a HRT of $0.5-1 \mathrm{~d} .[21,27]$ More recent studies with intermittent UASB reactors used for treating dairy wastewaters resulted in COD removal efficiencies of $94-96 \%$ and methanization efficiencies of the removed COD of $86-92 \%$ at OLR of $6 \mathrm{~kg} \mathrm{COD} \mathrm{L}^{-1} \mathrm{~d}^{-1}$ and HRT of 12h.[35]

Insights into what happens during the feedless periods are important to understand the functioning of the intermittent UASB systems. Literature presents several results for the degradation of dairy wastewater in batch reactors. [5-8] Yet, if effluent recirculation is applied during the feedless periods, the hydrodynamic conditions may significantly alter the COD removal mechanisms and subsequent biological degradation observed in feedless periods of intermittent systems. The importance of the hydrodynamic conditions is related to mass transfer mechanisms [36] and to adsorption phenomena responsible for the major percentage of initial COD removal from complex wastewaters in anaerobic systems.[37,38]

The recirculation of the treated effluent in a semicontinuous two-stage system combining continuous stirred tank reactor (CSTR) and UASB resulted in a higher yield of methane and suggested that the recirculation could support the hydrolysis step as well as avoiding nutrient loss at higher OLR, and thus improving the performance and the stability of the process.[24]

The upflow velocity $\left(V_{\text {up }}\right)$ is an important operational parameter in UASB reactors for maintaining the mixing of the substrate and biomass.[14] Several studies have demonstrated the importance of the liquid upflow velocity upon the kinetics of high-rate anaerobic systems.[39-44] The permissible limit of upflow velocity is $0.5-1.5 \mathrm{~m} \mathrm{~h}^{-1}$ described by many researchers.[45] Siang [46] maintained a $0.59 \mathrm{~m} \mathrm{~h}^{-1} V_{\text {up }}$ at a HRT of $13 \mathrm{~h}$ for the treatment of palm oil effluents. Keyser et al. [47] reported a $2 \mathrm{~m} \cdot \mathrm{h}^{-1} V_{\text {up }}$ at HRT of 1.25 days. In lab-scale UASB reactors inoculated with flocculent sludge and fed with dairy wastewater. Nadais et al. [22] reported a $V_{\text {up }}$ of $0.11 \mathrm{~m} \mathrm{~h}^{-1}$ at a $16 \mathrm{~h}$
HRT and observed that $V_{\text {up }}$ above $0.14 \mathrm{~m} \mathrm{~h}^{-1}$ (and HRT bellow $12 \mathrm{~h}$ ) caused biomass washout and the formation of scum and sludge layer on the top of the reactors. Torkian et al. [48] treated slaughterhouse wastewater and applied $V_{\text {up }}$ from 0.33 to $1.0 \mathrm{~m} \mathrm{~h}^{-1}$ while keeping a constant HRT of $2.4 \mathrm{~h}$ using a pilot-scale UASB reactor of $1 \mathrm{~m}^{3}$ capacity. While treating municipal wastewater in UASB reactor, Uemura and Harada [49] reported $0.426 \mathrm{~m} \mathrm{~h}^{-1} V_{\text {up }}$ at $4.7 \mathrm{~h}$ of HRT. Moawad et al. [50] used upflow velocities of $0.31-0.43 \mathrm{~m} \mathrm{~h}^{-1}$ at HRT of $4-3 \mathrm{~h}$ with a rectangular shaped UASB reactor for the treatment of municipal wastewater.

Some authors suggest that the substrates diffusion rate decreases with a higher flow velocity,[51] while other authors [52] found that the external mass transfer resistance can be decreased by increasing the flow velocity. Brito and Melo [53] reported that under conditions of turbulent liquid flow, and thus higher shear stress, the flow velocity had a pronounced effect on the biofilm thickness and compactness, leading to different mass transfer coefficients. If the bulk liquid suffers a shift in velocity, there is an increase in internal mass transfer coefficient.

Zeng et al. [54] modelled the dynamic behaviour of a UASB reactor and reported a linear dependence between the dispersion coefficient and the upflow velocity of the liquid. The experimental results of Gonzalez-Gil et al. [39] revealed that the variation in liquid upflow velocity did not affect the value of the apparent Monod constant for granular acetoclastic biomass, thus indicating that the external resistance to the mass transport could be neglected. Guiot et al. [55] verified that a rise in the liquid upflow velocity could cause a decrease in the acidogenic activity of the sludge and a rise in the post-acidogenic activity (propionate, acetate, $\mathrm{H}_{2}$ ), this effect being more pronounced for higher specific loading rates.

Studies by Chowdhury and Mehrotra [40] showed that the sludge bed in a UASB reactor had the hydraulic behaviour of a CSTR with bypass and evidenced that the reactor performance was influenced by the short-circuiting of the liquid through the sludge bed. Nadais [8] determined that the hydraulic behaviour of a lab-scale UASB reactor with a volume of $6 \mathrm{~L}$, operated at a $12 \mathrm{~h}$ HRT (upflow velocity of $0.072 \mathrm{~m} \mathrm{~h}^{-1}$ ) and fed with dairy wastewater at a load of $12 \mathrm{~g} \mathrm{COD} \mathrm{L}^{-1} \mathrm{~d}^{-1}$ was intermediate between a perfect CSTR and two CSTR in series.

The monitoring of the sludge volume index (SVI) of the sludge developed in a mesophilic UASB reactor showed that the settling ability of the sludge gradually improved in the first 120 days of operation, reaching a plateau thereafter.[56] The authors suggested that the improvement of the settling ability could provide a basis for keeping bed height constant despite shortened HRT. Leitão et al. [57] reported that decreasing the influent COD concentration led to a decreased settleability and increased expansion of the anaerobic sludge. The authors also reported that the sludge settleability apparently increased as the HRT 
decreased (and upflow velocity increased) and suggested the occurrence of a selection process in the sludge bed, that is, the washout of the voluminous light flocs leaving the well-settling aggregates in the reactor. Contrary to this suggestion, Guiot et al. [55] verified that the liquid upflow velocity had a direct effect upon the diameter of the biomass aggregates developed in a UASB reactor as a direct function of the hydrodynamic regime and not so much as a result of the specific washout of smaller biomass particles at higher upflow velocities.

In this framework, this investigation aimed at evaluating the influence of hydrodynamic conditions achieved through effluent recirculation upon the kinetics of dairy wastewater degradation in the feedless periods of intermittent UASB operation. The influence of effluent recirculation upon the sludge bed dynamics was also studied.

\section{Materials and methods}

For the assessment of the influence of effluent recirculation upon the feedless period of intermittent operation, two replicate lab-scale UASB reactors were used with a working volume of $6 \mathrm{~L}$, topped with a gas-solid-liquid separator and operated at mesophilic temperature $\left(35 \pm 1^{\circ} \mathrm{C}\right)$ by means of water jackets connected to thermostatic baths. The UASB reactors are shown in Figure 1. For comparison, batch tests were conducted in lab-scale reactors with no recirculation in order to assess the biodegradability of the substrate in mesophilic anaerobic conditions $\left(35 \pm 1^{\circ} \mathrm{C}\right)$. The batch reactors had working volumes of $5 \mathrm{~L}$ and the applied loads were 3 and $10 \mathrm{~g} \mathrm{CODL}^{-1}$. The inoculum sludge was adapted sludge taken from an industrial anaerobic reactor treating dairy wastewater with a specific methanogenic activity (SMA) of $0.25 \mathrm{~g}$ $\mathrm{CH}_{4}-\mathrm{COD} \mathrm{g}^{-1} \mathrm{VSS} \mathrm{d}^{-1}$. For the UASB tests, each reactor was seeded with approximately $4 \mathrm{~L}$ of flocculent biomass adapted to dairy wastewater with an SMA of $0.21 \mathrm{~g}$ $\mathrm{CH}_{4}-\mathrm{COD} \mathrm{g}^{-1} \mathrm{VSS} \mathrm{d}^{-1}$ and taken from an industrial dairy wastewater treatment plant. The SMA tests were conducted at mesophilic temperature $\left(35 \pm 1^{\circ} \mathrm{C}\right)$ with a VSS concentration of $5 \mathrm{~g} \mathrm{~L}^{-1}$ and $3 \mathrm{gCOD} \mathrm{L}^{-1}$ of sodium acetate as substrate.

The feed for the UASB reactors was prepared from dilution of semi-skimmed milk and supplemented with nutrients and alkalinity (sodium bicarbonate).[22] Table 1 presents the composition of the milk used for preparing the feed. For the batch reactors, the feed was prepared from diluted commercial semi-skimmed milk. Details of the batch reactors operation are given elsewhere.[8]

The UASB reactors were operated in a discontinuous mode where the feed was pumped into the reactor and then the produced effluent was recirculated in closed circuit, without any extra feeding, at a volumetric flow of $0.5 \mathrm{~L} \mathrm{~h}^{-1}$ (upflow velocity of $0.072 \mathrm{~m} \mathrm{~h}^{-1}$ ). Table 2 presents the experimental conditions for the five UASB tests performed in this work.

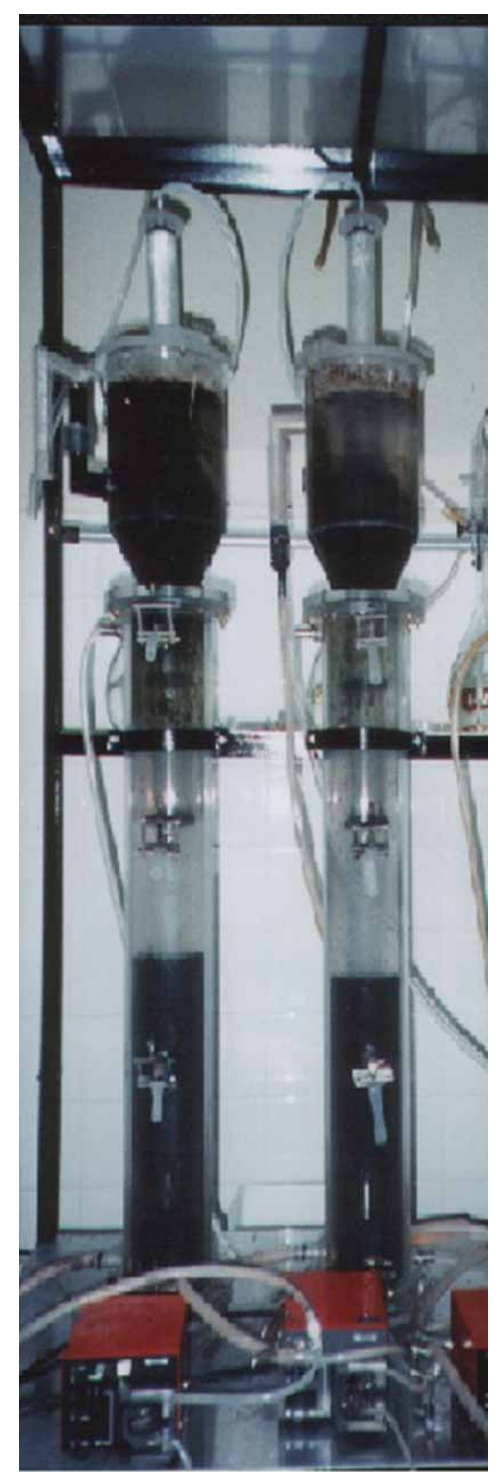

Figure 1. Laboratory-scale UASB reactors used in this work.

Table 1. Characterization of the milk used for feed.

\begin{tabular}{lc}
\hline Parameter & Value $\left(\mathrm{g} \mathrm{L}^{-1}\right)$ \\
\hline Proteins $^{\mathrm{a}}$ & 32 \\
Carbohydrates $^{\mathrm{a}}$ & 48 \\
Total lipids $^{\mathrm{a}}$ & 16 \\
Saturated lipids $^{\mathrm{a}}$ & 10 \\
Calcium $^{\mathrm{a}}$ & 1.2 \\
COD $^{\mathrm{b}}$ & 147.5 \\
\hline
\end{tabular}

Note: COD, chemical oxygen demand.

${ }^{a}$ Data from the producer of the commercial milk.

${ }^{\mathrm{b}}$ Experimental determination.

The monitoring plan was implemented at the beginning of recirculation and consisted of daily analysis of total $\mathrm{COD}$, paper-filtered $\mathrm{COD}\left(\mathrm{COD}_{\mathrm{pf}}\right)$, membrane-filtered $\mathrm{COD}\left(\mathrm{COD}_{\mathrm{mf}}\right)$, total and volatile suspended solids (TSS 
Table 2. Experimental set-up.

\begin{tabular}{lcc}
\hline Test & $\begin{array}{c}\text { Organic load } \\
\left(\mathrm{g} \mathrm{COD} \mathrm{L}^{-1}\right)\end{array}$ & $\begin{array}{c}\text { Biomass } \\
\left(\mathrm{g} \mathrm{VSS} \mathrm{L}^{-1}\right)\end{array}$ \\
\hline 1 & 0.33 & 4.8 \\
2 & 0.67 & 4.8 \\
3 & 4.5 & 4.5 \\
4 & 8.9 & 5.1 \\
5 & 17 & 4.3 \\
\hline
\end{tabular}

and VSS), $\mathrm{pH}$ and volatile fatty acids (VFA). Paper-filtered COD samples $\left(\mathrm{COD}_{\mathrm{pf}}\right)$ were prepared using paper filters with a pore diameter of $1.2 \mu \mathrm{m}$ (Whatman Inc. Reeve Angel, grade 403, Ø $4.7 \mathrm{~cm}$ ). Membrane-filtered COD samples $\left(\mathrm{COD}_{\mathrm{mf}}\right)$ were prepared with membrane filters with a pore diameter of $0.45 \mu \mathrm{m}$ (Schleicher \& Schuel Purabind, Ø $4.7 \mathrm{~cm}$ ). Membrane-filtered COD represents the soluble COD fraction while the paper-filtered COD represents the soluble and colloidal COD fraction.[31]

The produced biogas was measured by water displacement systems. Methane content in biogas was monitored using a gas chromatograph Shimadzu GC - 9a, equipped with a Supleco Molecular Sieve 5 A column and a Thermal Conductivity Detector $\left(T=100^{\circ} \mathrm{C}\right)$. Injection temperature was $45^{\circ} \mathrm{C}$ and helium was used as carrier gas $\left(P=4.4 \mathrm{~kg} \mathrm{~cm}^{-2}\right)$. VFA determination was carried out in a gas chromatograph Chrompack CP 9001 equipped with a Chrompack CP - sil5 - CB column and a flame ionization detector $\left(T=300^{\circ} \mathrm{C}\right)$. The injection temperature was $270^{\circ} \mathrm{C}$ and helium was used as carrier gas with a volumetric flow of $8 \mathrm{~mL} \mathrm{~min}^{-1}$.

All the results presented in this work are averages of two replicate reactors.

\section{Results and discussion}

\section{COD biodegradation in batch test (no recirculation)}

The anaerobic biodegradation of the substrate at mesophilic temperature $\left(35 \pm 1{ }^{\circ} \mathrm{C}\right)$ was calculated as the percentage of feed COD that was converted to methane. The tested substrate reached an anaerobic biodegradation of $(81 \pm 5) \%$ and $(85 \pm 6) \%$ for the batch tests performed with 3 and $10 \mathrm{~g} \mathrm{COD} \mathrm{L}^{-1}$, respectively. These results are in accordance with the values of $86-97.5 \%$ reported by Vidal et al. [58] for the biodegradability of milk with similar fat content and with the value of $89.1 \%$ presented by Nieto et al. [5] for milk wastewater.

\section{Anaerobic sludge settleability and sludge bed dynamics}

The initialSVI of the inoculum used in the tests with the UASB reactors with total recirculation of the treated effluent was $84 \pm 6 \mathrm{~mL} \mathrm{~g}^{-1}$ and the final SVI for the sludge at the end of each test is presented in Figure 2 in comparison with the results obtained with tests with no recirculation.[8]

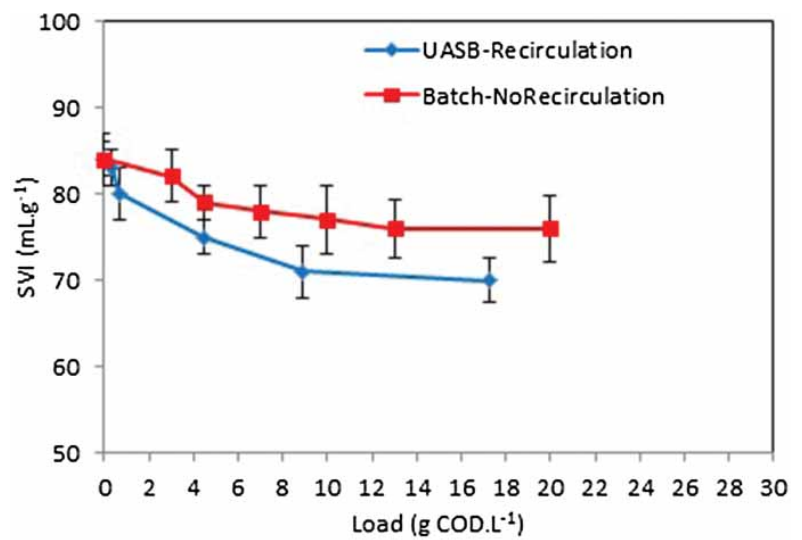

Figure 2. Evolution of SVI with applied load; data for batch tests reference.[8]

For both conditions, with and without effluent recirculation, it was observed that the tests with higher organic load resulted in sludge with lower SVI. The influence of the applied load on the SVI was more pronounced for the test with effluent recirculation. According to Leitão et al., [57] the formation of a more flocculent type of sludge with the application of low concentration influent, and relatively low upflow velocities, may be a result of natural selection, as flocculent sludge is characterized by a lower mass transfer resistance as compared with granular sludge.[59] This may explain the higher values of SVI obtained in this work for the sludge subjected to lower loads. The results for sludge bed high for the UASB test with the load of $8.9 \mathrm{~g} \mathrm{COD} \mathrm{L}^{-1}$ are presented in Figure 3 where it can be seen that during the first days of operation, the sludge bed expanded slightly to a maximum of $12.8 \%$ expansion in relation to the initial height. After the fifth day, the sludge bed started to contract, losing up to $15.5 \%$ of the initial bed height although the same liquid upflow velocity was kept $\left(0.072 \mathrm{~m} \mathrm{~h}^{-1}\right)$. These results imply that the initial sludge bed expansion was greatly due to the biogas that was formed during the degradation of the sugars

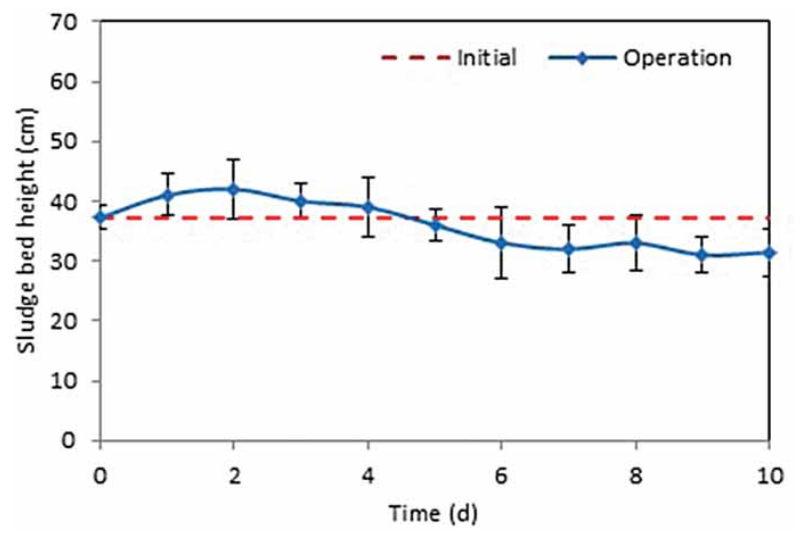

Figure 3. Evolution of sludge bed high for test $4(8.9 \mathrm{~g}$ $\left.\mathrm{CODL}^{-1}\right)$ 
and easily degradable substrates present in the substrate. Apparently, the applied upflow velocity, although very low $\left(0.072 \mathrm{~m} \mathrm{~h}^{-1}\right)$, resulted in the formation of more dense and compactable biomass aggregates.

\section{COD biodegradation in UASB reactors with total effluent recirculation (closed circuit)}

For all the tests performed in the UASB reactors with total effluent recirculation, the profiles of $\mathrm{COD}_{\mathrm{pf}}$, cumulative methane production, removal of $\mathrm{COD}_{\mathrm{pf}}$ and methanization of removed $\mathrm{COD}_{\mathrm{pf}}$ were obtained. Figures 4-7 present results for the two higher loads tested $\left(8.9 \mathrm{~g} \mathrm{~L}^{-1}\right.$ and $17 \mathrm{~g} \mathrm{COD} \mathrm{L}^{-1}$ ).

For all the organic loads tested, a significant decrease in $\mathrm{COD}_{\mathrm{pf}}$ was observed during the first day of the tests (Figures 4 and 5) with $75-90 \% \mathrm{COD}_{\mathrm{pf}}$ removal for all the tests except the higher load (only $43 \% \mathrm{COD}_{\mathrm{pf}}$ removal on the first day). From the second day onwards, the $\mathrm{COD}_{\mathrm{pf}}$ values are approximately similar, except for the higher load $\left(17 \mathrm{~g} \mathrm{COD} \mathrm{L} \mathrm{d}^{-1}\right)$ in which an important decrease in $\mathrm{COD}_{\mathrm{pf}}$ was observed on the second day (Figure 5). The values of volumetric methane production presented a tendency

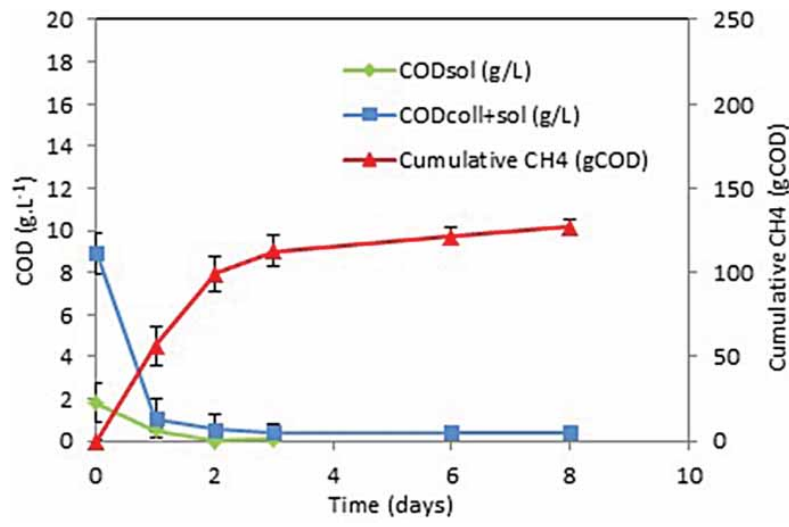

Figure 4. $\mathrm{COD}$ and $\mathrm{CH}_{4}$ profile for test $\left(8.9 \mathrm{~g} \mathrm{COD} \mathrm{L}^{-1}\right)$.

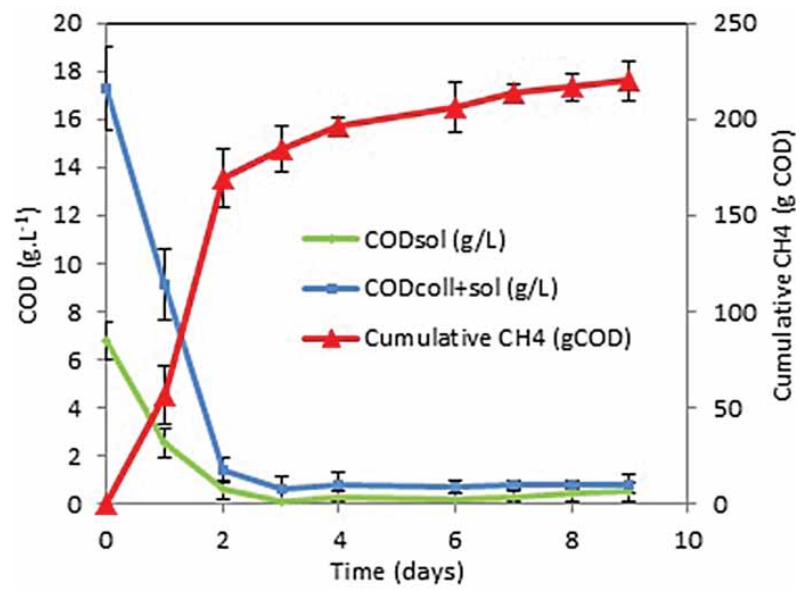

Figure 5. $\mathrm{COD}$ and $\mathrm{CH}_{4}$ profile for test $\left(17 \mathrm{~g} \mathrm{COD} \mathrm{L}^{-1}\right)$.

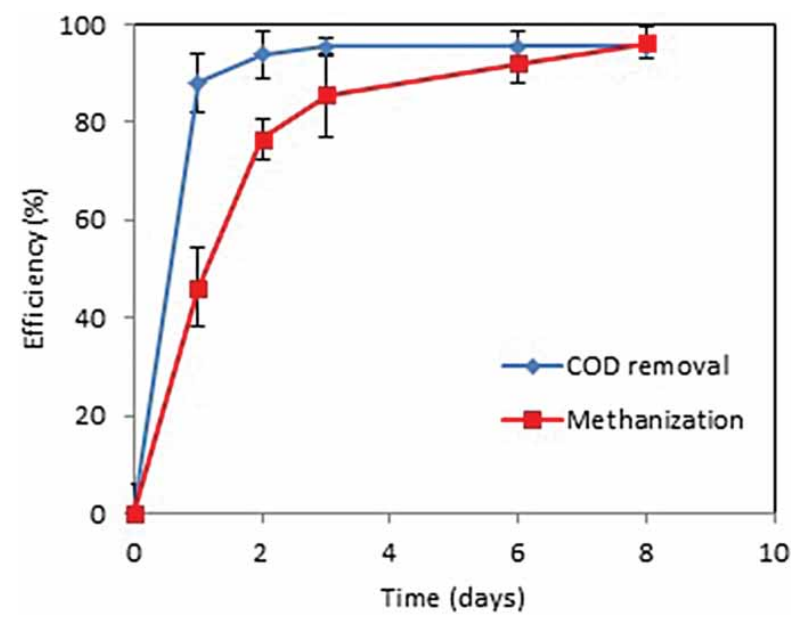

Figure 6. COD removal and methanization efficiencies for test $4\left(8.9 \mathrm{~g} \mathrm{COD} \mathrm{L}^{-1}\right)$.

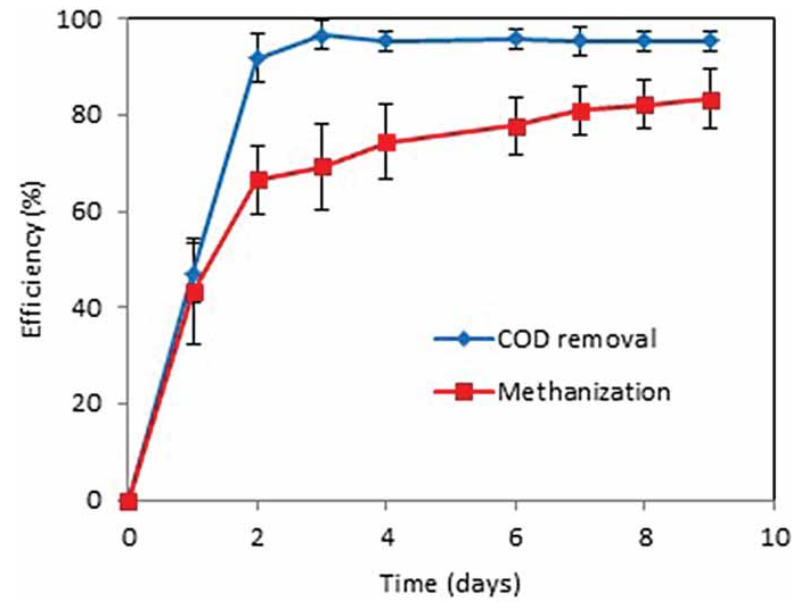

Figure 7. COD removal and methanization efficiencies for test $5\left(17 \mathrm{~g} \mathrm{COD} \mathrm{L}^{-1}\right)$.

towards stabilization only from the third day onwards for all the tests except for the lower load $\left(0.33 \mathrm{~g} \mathrm{COD} \mathrm{L} \mathrm{d}^{-1}\right.$, data not shown). With this lower load, the tendency to diminish the methane production was observed only after the fifth day of the test (data not shown).

For loadsup to $8.9 \mathrm{~g} \mathrm{COD} \mathrm{L}^{-1}$, the cumulative COD removal occurring until the second day is very similar to the COD removal observed on the first day (Figure 8). This means that the additional COD removal on the second day is very small in comparison with what was observed on the first day. In contrast, for the higher load $\left(17 \mathrm{~g} \mathrm{COD} \mathrm{L}^{-1}\right)$, by comparing the cumulative percentage removal attained on the first and the second days, it is possible to see that not all the substrate was removed on the first day.

A linear relation was found between the applied load and the volumetric methane production obtained on the first day (Figure 9) except for the higher load. In this case, a decrease in the ratio $\mathrm{CH}_{4} /$ load was observed. When correlating the total cumulative volume of $\mathrm{CH}_{4}$ produced until 


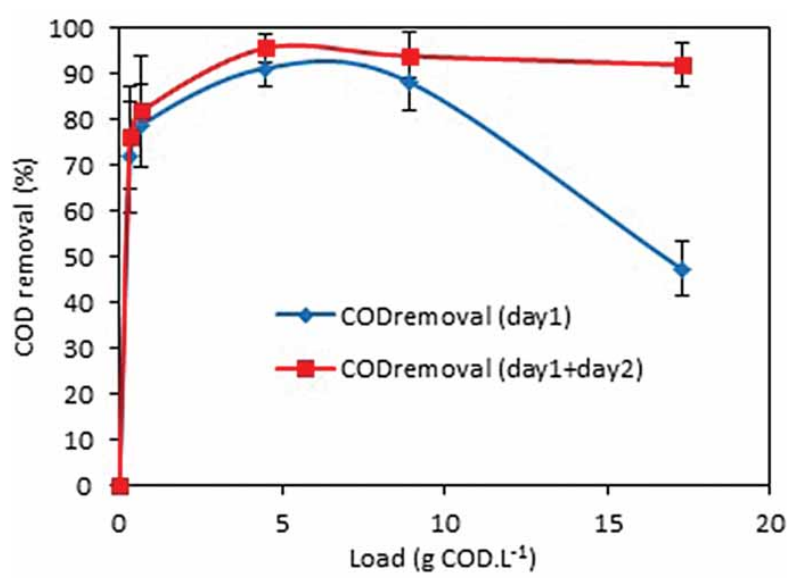

Figure 8. Evolution of COD removal with applied load.

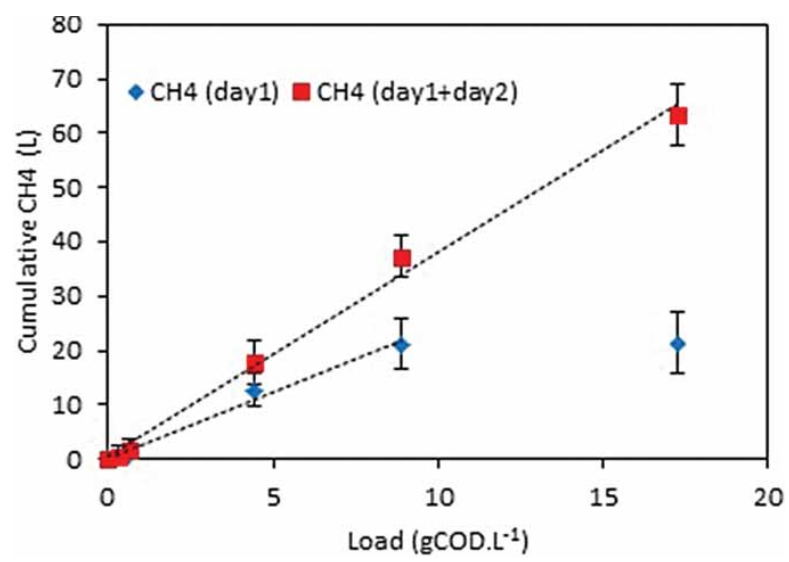

Figure 9. Correlation between applied load and methane production.

the second day with the applied loads, a linear correlation is observed for all the loads (Figure 9). This suggests that for the load range tested in this work, a two-day feedless period in the intermittent operation of UASB reactors would be sufficient for the degradation of the feed substrate. Figure 10 presents the values of methanization percentages of the removed $\mathrm{COD}_{\mathrm{pf}}$ attained on the first and second days of the tests as functions of the applied loads. The differences observed in the methanization of the removed substrate between the first and second days indicate that a part of the COD removed during the first day is methanized only on the second day. This result is in accordance with the proposed duration of two days for the feedless period of intermittent operation of UASB reactors treating dairy wastewater.[22]

The methane content in the produced biogas varied from $50 \%$ to $90 \%$ for all the tests, being higher by the end of each test. The soluble COD fraction $\left(\mathrm{COD}_{\mathrm{mf}}\right)$ is the fraction available for metabolization by the microorganism, and is around $20-40 \%$ of the $\mathrm{COD}_{\mathrm{pf}}$ (colloidal + soluble COD) in the beginning of tests (Figures 4 and 5). In all the tests, the average $\mathrm{pH}$ values varied between 7

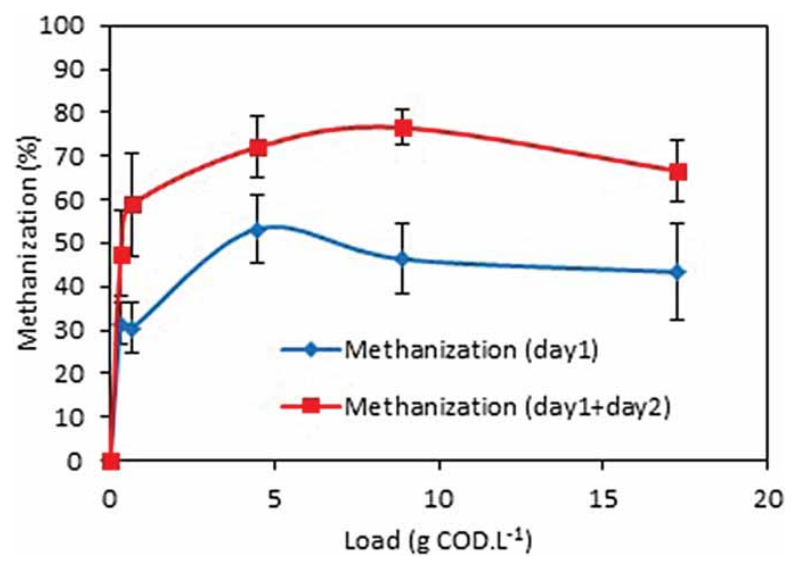

Figure 10. Evolution of methane production with applied load.

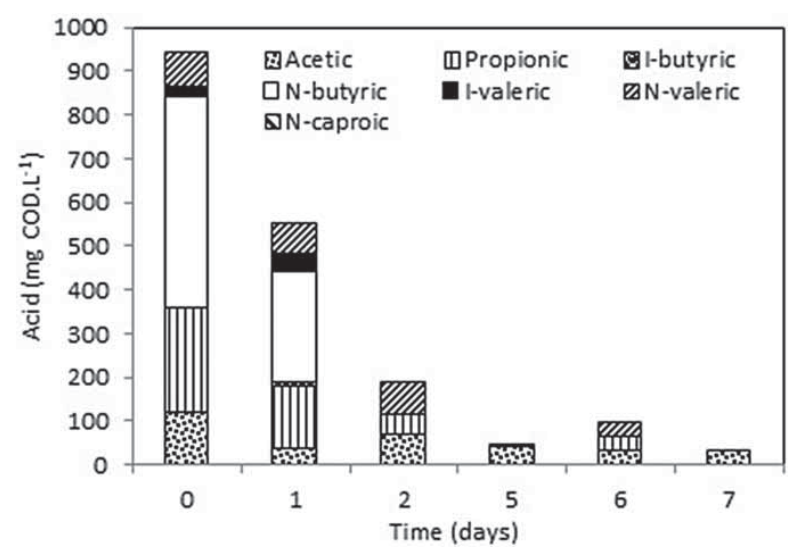

Figure 11. VFA profile for test 4 .

and 8, the lowest value reached being 6.5. The VFA concentrations determined in all the tests never surpassed $2 \mathrm{mg} \mathrm{HAc}^{-1}$, always being under the threshold toxicity limit of $3 \mathrm{~g} \mathrm{HAc} \mathrm{L}^{-1}$ suggested by Malina and Pohland.[38] As an example, Figure 11 presents the VFA profile for test 4 (load of $8.9 \mathrm{gCODL}^{-1}$ ) where it can be seen that a significant percentage of the produced VFA is butyric acid, an intermediate substrate related to the degradation of fatty matter and LCFA in anaerobic systems.[60]

The specific CODcolloidal + soluble removal rates $\left(q \mathrm{COD}_{\mathrm{pf}}\right)$ and the specific methane production rates $\left(q \mathrm{CH}_{4}\right)$ were obtained by the initial velocity method $(\Delta t=1 \mathrm{~d})$ and were adjusted to the Monod model Equation (1) and to the uncompetitive inhibition model or Haldane model Equation (2), both described in.[61] The least squares method was applied and commercial software Scientist (C) version 2.0 (1994) was used, with an integration method based on the Powell algorithm and initial values search by the double simplex method. The quality of the fitting was assessed by the coefficient of determination 
Table 3. Kinetic parameters.

\begin{tabular}{lcccc}
\hline Parameter & $\mathrm{COD}_{\mathrm{pf}^{\mathrm{a}}}$ & $\mathrm{CH}_{4}{ }^{\mathrm{a}}$ & $\mathrm{COD}_{\mathrm{pf}}{ }^{\mathrm{b}}$ & $\mathrm{CH}_{4}{ }^{\mathrm{b}}$ \\
\hline$q_{\max }\left(\mathrm{d}^{-1}\right)$ & 3.04 & 1.17 & 2.4 & 2.3 \\
$K_{\mathrm{S}}\left(\mathrm{g} \mathrm{L}^{-1}\right)$ & 9.39 & 6.71 & 9.6 & 13.0 \\
$r^{2}$ & 0.99 & 0.98 & 0.99 & 0.99 \\
\hline
\end{tabular}

${ }^{\mathrm{a}}$ This work.

${ }^{\mathrm{b}}$ Reference.[8]

$r^{2}$, see Figure 10 and Table 3:

$$
\begin{aligned}
q & =\frac{q_{\max }}{K_{\mathrm{s}}+S}, \\
q & =\frac{q_{\max }}{1+\left(K_{\mathrm{s}} / S\right)+\left(S / K_{i}\right)},
\end{aligned}
$$

where $q$ is the specific substrate removal rate ( $\mathrm{g}$ CODg $\left.\mathrm{VSS} \mathrm{d}^{-1}\right) ; q_{\max }$ the maximum substrate specific removal rate $\left(\mathrm{g} \mathrm{CODg} \mathrm{VSS} \mathrm{d}^{-1}\right) ; K_{\mathrm{S}}$ the half-velocity constant $\left(\mathrm{g} \mathrm{L}^{-1}\right), K_{\mathrm{i}}$ the Haldane inhibition constant $\left(\mathrm{g} \mathrm{L}^{-1}\right)$ and $S$ the substrate concentration $\left(\mathrm{g} \mathrm{L}^{-1}\right)$.

According to the values of $r^{2}$, the model that provided a better fit of the experimental data was the Monod model (Figure 12). This was due to the fact that the removal of paper-filtered COD (CODcolloidal + soluble) expresses not only the biological removal but also the removal by physical-chemical mechanisms like entrapment and/or adsorption of substrates onto the sludge particles. As a consequence, no apparent inhibition is detected and the Monod model adequately fits the data. On the other hand, the specific methane production $\left(q \mathrm{CH}_{4}\right)$ rate which expresses the true biological degradation of the substrate was also better modelled with the Monod model because the loads used in this work were relatively low and no substrate inhibition was detected. Results from Nadais [8] obtained

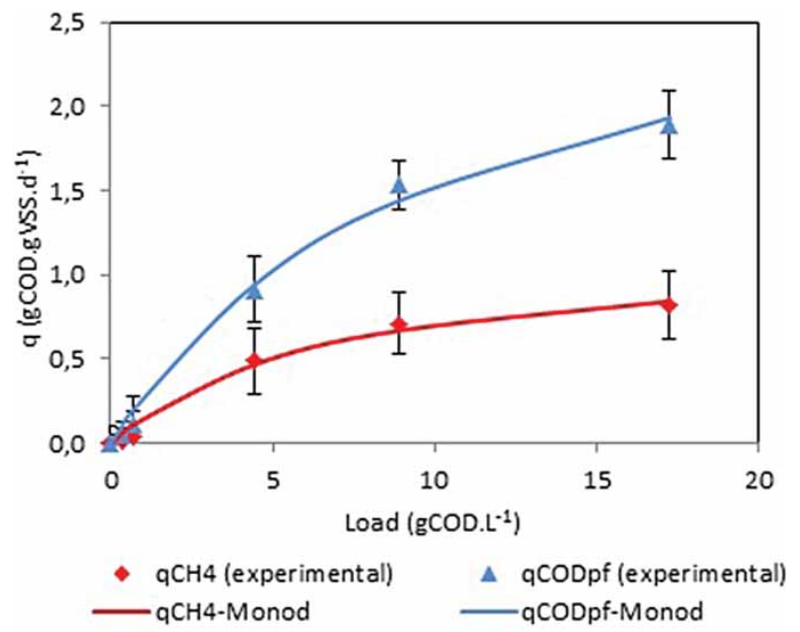

Figure 12. Fitting of experimental data to the Monod model. for batch tests with milk substrates and with no recirculation showed that substrate inhibition effects were detected only for loads above $10 \mathrm{~g} \mathrm{COD} \mathrm{L}^{-1}$. The effect of recirculating the effluent and the resulting improvement of the mixing in the system may have contributed to lower the apparent inhibition. According to Pavlostathis and GiraldoGomez, [62] the value of the half saturation constant $K_{\mathrm{S}}$ tends to increase when the mass transfer limitations are more severe. It is also worth noting that the hydrodynamic conditions in the reactors are determinant for the mass transfer effects and, consequently, on the values of the kinetic constants. Generally, in continuous reactors, the mass transfer limitations are less than in batch reactors.[63]

The specific rate of methane production $\left(q \mathrm{CH}_{4}\right)$ is approximately $45 \%$ of the specific $\mathrm{COD}_{\mathrm{pf}}$ removal rate (Figure 13) which is justified by the fact that these rates were calculated using the initial velocity method $(\Delta t=1 \mathrm{~d})$ and there is a lag between initial COD removal and methane production. This discrepancy is due to the fact that not all the organic matter is available for the microorganisms to degrade since it was adsorbed onto the biomass particles, causing a methane production lower than the expected from the observed COD removal. Nadais et al. [37] reported that the adsorption of milk substrates onto anaerobic sludge increased for a higher degree of sludge adaptation to the substrate and also that the adsorption phenomena take place very fast, reaching a plateau within 15-30 min of contact between the milk substrate and the sludge. The results obtained in the present work confirm the rapid adsorption of organic substrate onto the biological sludge reported by Hwu [64] and Nadais et al. [37].

Figure 14 and Table 3 present a comparison of the specific COD removal rates obtained in this work and those obtained in batch reactors with no recirculation with a biomass content of $5 \mathrm{~g} \mathrm{VSS} \mathrm{L}^{-1}$.[8] It can be seen that for

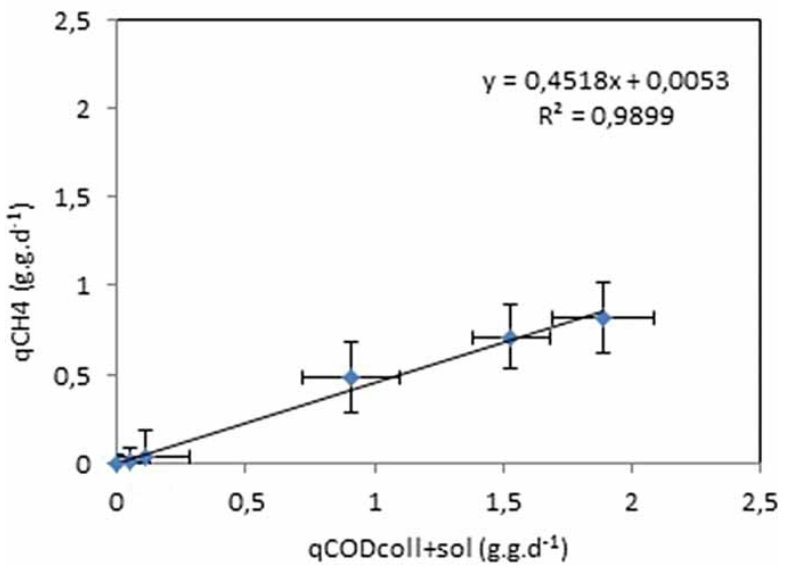

Figure 13. Relation between specific COD removal rate and specific methane production rate. $r^{2}$, correlation coefficient. 


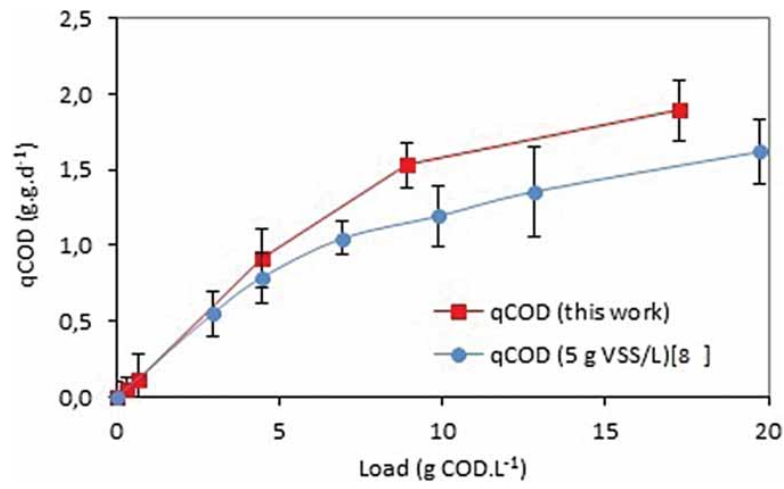

Figure 14. Comparison of COD removal rates from this work and literature.[8]

loads above $5 \mathrm{~g} \mathrm{COD} \mathrm{L}^{-1}$, recirculation improves the COD removal rate in about $30 \%$ for tests performed with the same VSS content compared with the results with no recirculation. The half saturation constant obtained in this work for the removal of CODcolloidal + soluble was $9.4 \mathrm{~g} \mathrm{~L}^{-1}$, lower than the value obtained for the batch tests with no recirculation $\left(9.6 \mathrm{~g} \mathrm{~L}^{-1},[8]\right)$, indicating lower mass transfer limitations with effluent recirculation. An even wider difference may be observed for the half saturation constants referring to methane formation (Table 3 ). This means that the recirculation of the treated effluent and the hydrodynamic conditions have a significant beneficial influence upon the kinetics of the degradation process in intermittent anaerobic systems.

Figure 15 presents the COD balances for test 4 (organic load of $8.9 \mathrm{~g} \mathrm{COD} \mathrm{L}^{-1}$ ), while Figure 16 presents the COD balances for a test performed in similar conditions but with no effluent recirculation, with an organic load of $9 \mathrm{~g} \mathrm{CODL}^{-1}$ and $5 \mathrm{~g} \mathrm{VSS} \mathrm{L}^{-1}$, [8]. Surprisingly, it can be seen that initial methane production was faster in the test with no recirculation. Yet, initial adsorption (retained COD) is more pronounced in the test with effluent recirculation probably due to a more complete contact between the substrate and the biomass. Although initial adsorption is higher with effluent recirculation, also the substrate

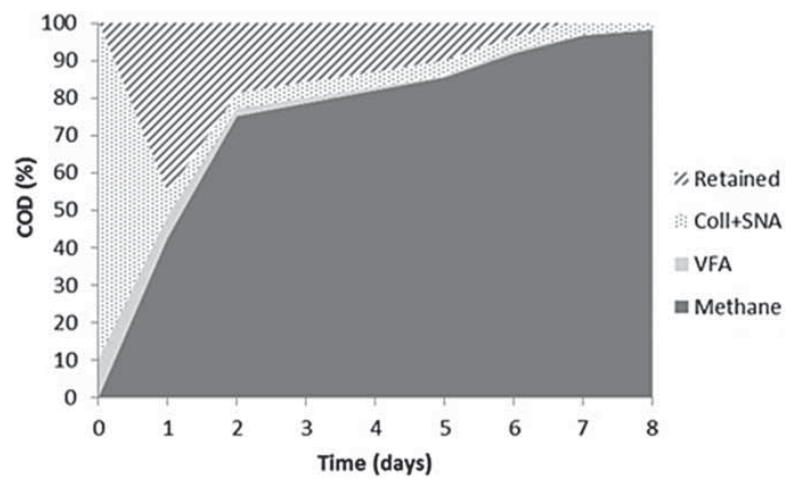

Figure 15. COD balance for test $4\left(8.9 \mathrm{gCODL}^{-1}\right)$; coll $=$ colloidal, $\mathrm{SNA}=$ soluble not acidified .

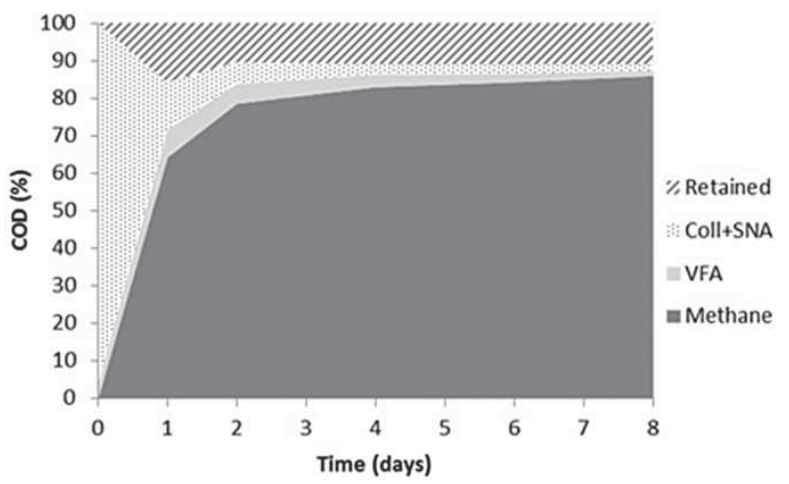

Figure 16. COD balance for a batch test without recirculation with a load of $9 \mathrm{~g} \mathrm{COD} \mathrm{L}^{-1}$ and $5 \mathrm{~g} \mathrm{VSS} \mathrm{L}^{-1}$ (adapted from [8]); coll, colloidal; SNA, soluble not acidified.

degradation is higher for this condition, leading to higher methanization efficiency. The maximum COD biodegradation attained with effluent recirculation at the load of $8.9 \mathrm{~g} \mathrm{COD} \mathrm{L}^{-1}$ was $96 \%$, a higher value than the one obtained in the batch test (maximum $85 \%$ ).

These results are in agreement with those previously reported by Nadais et al.,[21] who described an improvement of intermittent UASB reactor performance when effluent recirculation was applied during the feedless periods (methanization rose to $95 \%$ as compared to $80-88 \%$ attained with no effluent recirculation).

The results obtained in this work also suggest that for organic loads above $10 \mathrm{~g} \mathrm{COD} \mathrm{L}^{-1}$, the feedless periods of intermittent operation should be longer than the feed periods as has been suggested by Coelho et al.[29] On the other hand, in this work, it was confirmed that the monitoring of high-rate reactors treating complex fat containing wastewater based on the monitoring of the COD of the produced effluent may be misleading in what concerns the real biological degradation as stated by Nadais et al. [22] and by Jeganathan et al. [25]. This is because the difference between the feed COD and the effluent COD may not express the degradation of the substrate since accumulation may frequently occur in the sludge bed. The adequate parameter to monitor high-rate anaerobic reactors should be the efficiency of methanization of the removed COD.

\section{Conclusions}

In laboratory experiments of UASB reactors with total effluent recirculation treating dairy wastewater, there is a rapid COD removal on the first day of the tests, evidenced by the decrease in CODcolloidal + soluble, the removal of which is not followed by a biological degradation evidenced by $\mathrm{CH}_{4}$ production. This is due to adsorption of the organic matter onto the surface of the biological sludge the adsorption of which is faster than biological degradation. The $\mathrm{CH}_{4}$-specific production rate, calculated by the initial velocity method $(\Delta t=1 \mathrm{~d})$, was about $45 \%$ of the 
specific CODcolloidal + soluble removal rate. This confirms that the monitoring of high-rate reactors treating fat containing substrates should be based on the efficiency of methanization of removed COD rather than on the COD removal efficiency. The discrepancy between the initial COD removal and the $\mathrm{CH}_{4}$ production was observed mostly on the first day of the tests fading on the second day, which suggests that a period for intermittency in UASB reactors treating dairy wastewater should be longer than one day and possibly two days.

In what concerns the influence of the hydrodynamic conditions upon the behaviour of high-rate reactors treating milk wastewaters, it can be said that effluent recirculation during feedless periods improved significantly (up to $30 \%$ increase) the specific CODcolloidal + soluble removal rate in comparison with what was observed in classical batch reactors with no recirculation. A more complete substrate degradation as measured by methanization efficiency was also observed with effluent recirculation. The observed bed expansion was due to the biogas production and the application of effluent recirculation led to a sludge bed contraction after all the substrates were degraded. The settleability of the anaerobic sludge improved by the introduction of effluent recirculation, this effect being more pronounced for the higher loads.

\section{Disclosure statement}

No potential conflict of interest was reported by the authors.

\section{Funding}

This work was performed with funding from FCTFundação para a Ciência e Tecnologia, Portugal (PTDC/ AMB/65025/2006).

\section{References}

[1] Buffiere P, Mirquez LD, Steyer JP, Bernet N, Delgenes JP. Anaerobic digestion of solid wastes needs research to face an increasing industrial success. Int J Chem React Eng. 2008;6:94-113.

[2] Appels L, Lauwers J, Degrève J, Helsen L, Lievens B, Willems K, Van Impe J, Dewil R. Anaerobic digestion in global bio-energy production: potential and research challenges. Renew Sust Energy Rev. 2011;15: 4295-4301.

[3] Cirne DG, Paloumet X, Björnsson L, Alves MM, Mattiasson B. Anaerobic digestion of lipid-rich waste - effects of lipid concentration. Renew Energy. 2007;32:965-975.

[4] Angelidaki I, Ahring BK. Effects of free long-chain fatty acids on thermophilic anaerobic digestion. App Microbiol Biotechnol. 1992;37:808-812.

[5] Nieto PP, Hidalgo D, Irusta R, Kraut D. Biochemical methane potential (BMP) of agro-food wastes from the Cider Region (Spain). Water Sci Techn. 2012;66(9): 1842-1848.
[6] Belançon D, Fuzzato MC, Gomes DRS, Cichello GCV, De Pinho SC, Ribeiro R, Tommaso G. A comparison of two bench-scale anaerobic systems used for the treatment of dairy effluents. Int J Dairy Technol. 2010;63: 290-296.

[7] Dębowski M, Krzemieniewski M, Zieliński M, Dudek M, Grala A. Respirometric studies on the effectiveness of biogas production from wastewaters originating from dairy, sugar and tanning industry. Environ Technol. 2013;34(11):1439-1446.

[8] Nadais H. Dairy wastewater treatment with intermittent UASB reactors [Ph.D. dissertation]. Aveiro: University of Aveiro; 2002 (in portuguese).

[9] Saléh BB, Campos CMM, Figueiredo JG. Levantamento de parâmetros cinéticos medidos em reator anaeróbio de manta de lodo (UASB) em escala-piloto tratando efluentes de laticínio. Acta Scientiarum Technology. 2009;31(1): 51-56.

[10] Borja R, Banks CJ. Kinetics of upflow anaerobic sludge blanket reactor treating ice-cream wastewater. Environ Technol. 1994;15(3):219-232.

[11] Tauseef SM, Abbasi Tasneem, Abbasi SA. Energy recovery from wastewaters with high-rate anaerobic digesters. Renew Sustain Energy Rev. 2013;19:704-741.

[12] Rajagopal R, Saady NMC, Torrijos M, Thanikal JV, Hung YT. Sustainable agro food industrial wastewater treatment using high rate anaerobic process. Water Environ Res. 2013;5(1):292-311.

[13] Lim SJ, Kim TH. Applicability and trends of anaerobic granular sludge treatment processes. Biomass Bioenerg. 2014;60:189-202.

[14] Latif MA, Ghufran R, Wahid ZA, Ahmad A. Integrated application of upflow anaerobic sludge blanket reactor for the treatment of wastewaters. Water Res. 2011;45:46834699.

[15] Luostarinen SA, Jukka AR. Anaerobic on-site treatment of black water and dairy parlour wastewater in UASBseptic tanks at low temperatures. Water Res. 2005;39: 436-448.

[16] Gavala HN, Kopsini H, Skiada IV, Stamatelatou K, Lyberatos G. Treatment of dairy wastewater using an upflow anaerobic sludge blanket reactor. J Agr Eng Res. 1999;73:59-63.

[17] Tawfik A, Sobhey M, Badawy M. Treatment of a combined dairy and domestic wastewater in an up-flow anaerobic sludge blanket (UASB) reactor followed by activated sludge (AS system). Desalination. 2008;227:167-177.

[18] Jedrzejewska-Cicinska M, Kozak K, Krzemieniewski M. A comparison of the technological effectiveness of dairy wastewater treatment in Anaerobic UASB reactor and anaerobic reactor with an innovative design. Environ Technol. 2007;28:1127-1133.

[19] Passeggi M, Lopez I, Borzacconi L. Integrated anaerobic treatment of dairy industrial wastewater and sludge. Water Sci Technol. 2009;59:501-506.

[20] Campos CMM, Luiz FAR, Botelo CG, Damasceno LHS. The efficiency of UASB reactor treating dairy effluent at different organic loading rates. Ciênc Agrotec. 2004;28(6):1376-1384.

[21] Nadais H, Capela I, Arroja L. Intermittent vs. continuous operation of upflow anaerobic sludge bed reactors for dairy wastewater and related microbial changes. Water Sci Technol. 2006;54(2):103-109.

[22] Nadais H, Capela I, Arroja L. Treatment of dairy wastewater in UASB reactors inoculated with flocculent biomass. Water SA. 2005;31(4):603-607. 
[23] Buntner D, Sánchez A, Garrido JM. Feasibility of combined UASB and MBR system in dairy wastewater treatment at ambient temperatures. Chem Eng J. 2013;230: 475-481.

[24] Aslanzadeh S, Rajendran K, Jeihanipour A, Taherzadeh MJ. The effect of effluent recirculation in a semicontinuous two-stage anaerobic digestion. Energies. 2013;6: 2966-2981.

[25] Jeganathan J, Nakhla G, Bassi A. Long-term performance of high-rate anaerobic reactors for the treatment of oily wastewater. Environ Sci Technol. 2006;40:6466-6472.

[26] Petruy R, Lettinga G. Digestion of a milk-fat emulsion. Bioresour Technol. 1997;61:141-149.

[27] Nadais H, Capela I, Arroja L, Duarte A. Optimum cycle time for intermittent UASB reactors treating dairy wastewater. Water Res. 2005;39(8):1511-1518.

[28] Passeggi M, López I, Borzacconi L. Modified UASB reactor for dairy industry wastewater: performance indicators and comparison with the traditional approach. J Clean Prod. 2012;26:90-94.

[29] Coelho N, Rodrigues A, Arroja L, Capela I. Effect of non-feeding period length on the intermittent operation of UASB reactors treating dairy effluents. Biotechnol Bioeng. 2007;96(2):244-249.

[30] Viñas M, Galain C, Lois M. Treatment of proteic wastewater in continuous and intermittent UASB reactors. VI international symposium on Anaerobic Digestion; 1991;1:321327; São Paulo, Brazil,.

[31] Sayed S. Anaerobic treatment of slaughterhouse wastewater using the UASB process [Ph.D. dissertation]. Wageningen: Agricultural University of Wageningen; 1987.

[32] Sayed S, Fergala M. Two-stage UASB concept for treatment of domestic sewage including sludge stabilisation process. Water Sci Technol. 1995;32(11):55-63.

[33] Gonçalves MR, Costa JC, Marques IP, Alves MM. Strategies for lipids and phenolics degradation in the anaerobic treatment of olive mill wastewater. Water Res. 2012;46(6):1684-1692.

[34] Palatsi J, Laureni M, Andrés MV, Flotats X, Nielsen HB, Angelidaki I. Recovery strategies from long-chain fatty acids inhibition in anaerobic thermophilic digestion of manure. Bioresour Technol. 2009;100(20):45884596.

[35] Couras CS, Louros VL, Grilo AM, Leitão JH, Capela MI, Arroja LM, Nadais MH. Effects of operational shocks on key microbial populations for biogas production in UASB (upflow anaerobic sludge blanket) reactors. Energy. 2014;73:866-874

[36] Pereira MA, Pires OC, Mota M, Alves MM. Anaerobic biodegradation of oleic and palmytic acids: evidence of mass transfer limitations caused by long chain fatty acid accumulation onto the anaerobic sludge. Biotechnol Bioeng. 2005;92(1):15-23.

[37] Nadais H, Capela I, Arroja L, Duarte A. Biosorption of milk substrates onto anaerobic flocculent and granular sludge. Biotechnol Prog. 2003;19:1053-1055.

[38] Malina JE, Pohland F. Design of anaerobic processes for the treatment of industrial and municipal wastes. Lancaster (PA): Technomic Publishing Company, Inc.; 1992

[39] Gonzalez-Gil G, Seghezzo L, Lettinga G, Kleerebezem R. Kinetics and mass-transfer phenomena in anaerobic granular sludge. Biotechnol Bioeng. 2001;73(2): 125-134.

[40] Chowdhury R, Mehrotra I. Minimization of short-circuiting flow through upflow anaerobic sludge blanket reactor. J Environ Eng-ASCE. 2004;130(9):951-959.
[41] Kalyushnyi SV, Fedorovich VV, Lens P. Dispersed plug flow model for upflow anaerobic sludge bed reactors with focus on granular sludge dynamics. J Ind Microbiol Biotechnol. 2006;33(3):221-237.

[42] Fuentes M, Aguirre PA, Scenna NJ. Heterogeneous anaerobic biofilm reactor models application to UASB, EGSB and AFB reactors, 10th International Symposium on Process Systems Engineering. Comput-Aided Chem Eng. 2009;27:297-302.

[43] Bhattacharyya D, Singh KS. Understanding the mixing pattern in an anaerobic expanded granular sludge bed reactor: effect of liquid recirculation. J Environ Eng-ASCE. 2010;136(6):576-584.

[44] Chen XG, Zheng P, Qaisar M, Tang CJ. Dynamic behavior and concentration distribution of granular sludge in a super-high-rate spiral anaerobic bioreactor. Biores Technol. 2012;111:134-140.

[45] Santos ARL, Aquino SF, Carvalho CF, Vierira LA, Gontijo ESJ. Characterization and treatability of wastewater from a dying hood of a furniture industry. Eng Sanit Amb. 2010;15(4):357-366.

[46] Siang LC. Biodegradation of oil and grease in upflow anaerobic sludge blanket reactor for palm oil mill effluent treatment [MSc. dissertation]. Kuala Lumpur: University Teknology Malaysia; 2006.

[47] Keyser M, Witthuhn RC, Ronquest L.-C., Britz TJ. Treatment of winery effluent with upflow anaerobic sludge blanket (UASB)-granular sludges enriched with Enterobacter sakazakii. Biotechol Lett. 2003;25:18931898.

[48] Torkian A, Eqbali A, Hashemian SJ. The effect of organic loading rate on the performance of UASB reactor treating slaughterhouse effluent. Resour Conserv Recy. 2003;40:111.

[49] Uemura S, Harada H. Treatment of sewage by a UASB reactor under moderate to low temperature conditions. Bioresour Technol. 2000;72:275-282.

[50] Moawad A, Mahmoud UF, El-Khateeb MA, El-Molla E. Coupling of sequencing batch reactor and UASB reactor for domestic wastewater treatment. Desalination. 2009;242:325-335.

[51] Beyenal H, Lewandowski Z. Combined effect of substrate concentration and flow velocity on effective diffusivity in biofilms. Water Res. 2000;34(2):528-538.

[52] Zaiat M, Vieira LGT, Foresti E. Liquid phase mass transfer in fixed bed of polyurethane foam matrices containing immobilized anaerobic sludge. Biotechnol Technol. 1996;10(2):121-126.

[53] Brito AG, Melo LF. Mass transfer coefficients within anaerobic biofilms: effects of external liquid velocity. Water Res. 1999;33(17):3673-3678.

[54] Zeng Y, Mu SJ, Lou SJ, Tartakovsky B, Guiot SR, Wu P. Hydraulic modeling and axial dispersion analysis of UASB reactor. Biochem Eng J. 2005;25(2):113-123.

[55] Guiot SR, Arcand Y, Chavarie C. Advantages of fluidization on granular size and activity development in upflow anaerobic sludge bed reactors. Water Sci Technol. 1992;26(34):897-906

[56] Ahn Y, Song YJ, Kim HS, Lee YJ, Park S. Physicochemical and microbial monitoring of UASB sludge during start-up of mesophilic reactor. Key Eng. Mat. 2005;277-279:552558

[57] Leitão RC, Santaellla ST, van Haandel AC, Zeeman G, Lettinga G. The effect of operational conditions on the hydrodynamic characteristics of the sludge bed in UASB reactors. Water Sci Technol. 2011;64(9): 1935-1941. 
[58] Vidal G, Carvalho A, Méndez R, Lema JM. Influence of the content in fats and proteins on the anaerobic biodegradability of dairy wastewaters. Bioresour Technol. 2000;74:231-239.

[59] Nicolella C, van Loosdrecht MCM, Heijnen JJ. Wastewater treatment with particulate biofilm reactors. J Biotechnol. 2000;80:1-33.

[60] Silvestre G, Rodríguez-Abalde A, Fernández B, Flotats X, Bonmatí A. Biomass adaptation over anaerobic co-digestion of sewage sludge and trapped grease waste. Bioresour Technol. 2011;102:6830-6836.
[61] Desjardins B, Lessard P. Modélisation du procédé de digestion anaérobie. Sciences et Techniques de L'eau. 1992;25(2):119-136.

[62] Pavlostathis S, Giraldo-Gomez E. Kinetics of anaerobic treatment. Water Sci Technol. 1991;24(8):35-39.

[63] Rinzema A, Boone M, Vanknippenberg K, Lettinga G. Effect of long-chain fatty-acids in aerobic-digestion. Water Environ Res. 1994;66(1):40-49.

[64] Hwu CS. Enhancing anaerobic treatment of wastewaters containing oleic acid [ $\mathrm{PhD}$ thesis]. Wageningen: Agricultural University of Wageningen; 1997. 